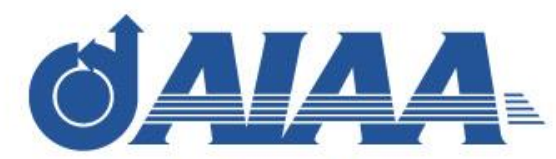

Shaping the Future of Aerospace

\title{
Selection of High Temperature Organic Materials for Future Stirling Convertors
}

E. Eugene Shin

Ohio Aerospace Institute (OAI)/NASA-GRC

15th IECEC/AIAA Propulsion \& Energy, 10 - 12 July, 2017

Atlanta, Georgia 


\section{Collaborators and Contributors}

This paper presents an overview of extensive work started at 2012 which involved numerous dedicated collaborators and contributors:

$>$ Dan Scheiman, Paula Heimann, Andrew Ring, OAI/NASA-GRC; Robert Pelaez, Sal Oriti, NASA-GRC; Chris Burke, Tim Ubienski, Tony Kapucinski, SLI/GRC-FTH; D. Jordan McCrone, GRC-LMA/VPL; and Samuel Slingluff, summer interns at NASA-GRC.

$>$ Mike Gorbulja, KOL-CAP Manuf.; Kerry Arnold, Cliff Fralick et al., Sunpower, Inc.; Mike Booker, CTL Inc.; Steve Hassman, Long-Lok Corporation.

$>$ Scott Wilson, Wayne Wong, Terry O'Malley, Jim Withrow, Lee Mason, NASA-GRC, for project guidance and management,

$>$ Tiffany Williams, NASA-GRC, for reviewing various reports and this paper.

$>$ This work was sponsored by the GRC-Radioisotope Power System (RPS) program office with funding from Science Mission Directorate (SMD). 


\section{Table of Contents}

- Backgrounds; Objectives; Overall Program Plan

- Materials and Processes

- Experimental

- Material Property Testing; Thermal Aging; TCIOP Testing

- Results and Discussion

- Initial Screening and Down-selection

- Extended Property-Performance Evaluations

- Functional Performance

- Long-term Thermal Stability

- TCIOP Material Compatibility

- Summary and Conclusions

- Future Work Plan 


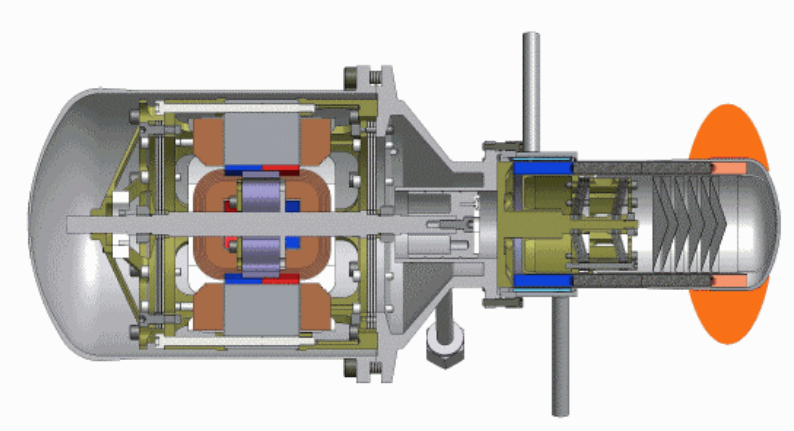

- Organics in Stirling convertors for design flexibility or unique properties and functionalities, such as bonding, potting, sealing, thread locking, insulation, and lubrication: a total of $\sim 22 \mathrm{gram}$

- SOA Convertor operating environment

- Pressurized with dry inert gas and hermetically sealed, but potential outgasses from organics or residual contaminants

- Elevated temperatures, $\sim 90-120^{\circ} \mathrm{C}$, and radiation exposures

- Long mission cycles up to 17 years, such as deep space explorations

- In future convertors, much higher operating temperature, $\sim 165-$ $200^{\circ} \mathrm{C}$, for improved efficiency \& performance

$\rightarrow H T$ organics should be screened \& evaluated! 


\section{Objectives}

- Screen, evaluate, and validate high temperature organic materials for future Stirling convertor applications, more specifically in terms of

- Performance, durability, and reliability

- Material compatibility

- Identify application limits of the candidate materials, and develop their performance and lifetime predictions 


\section{Overall Program Plan}

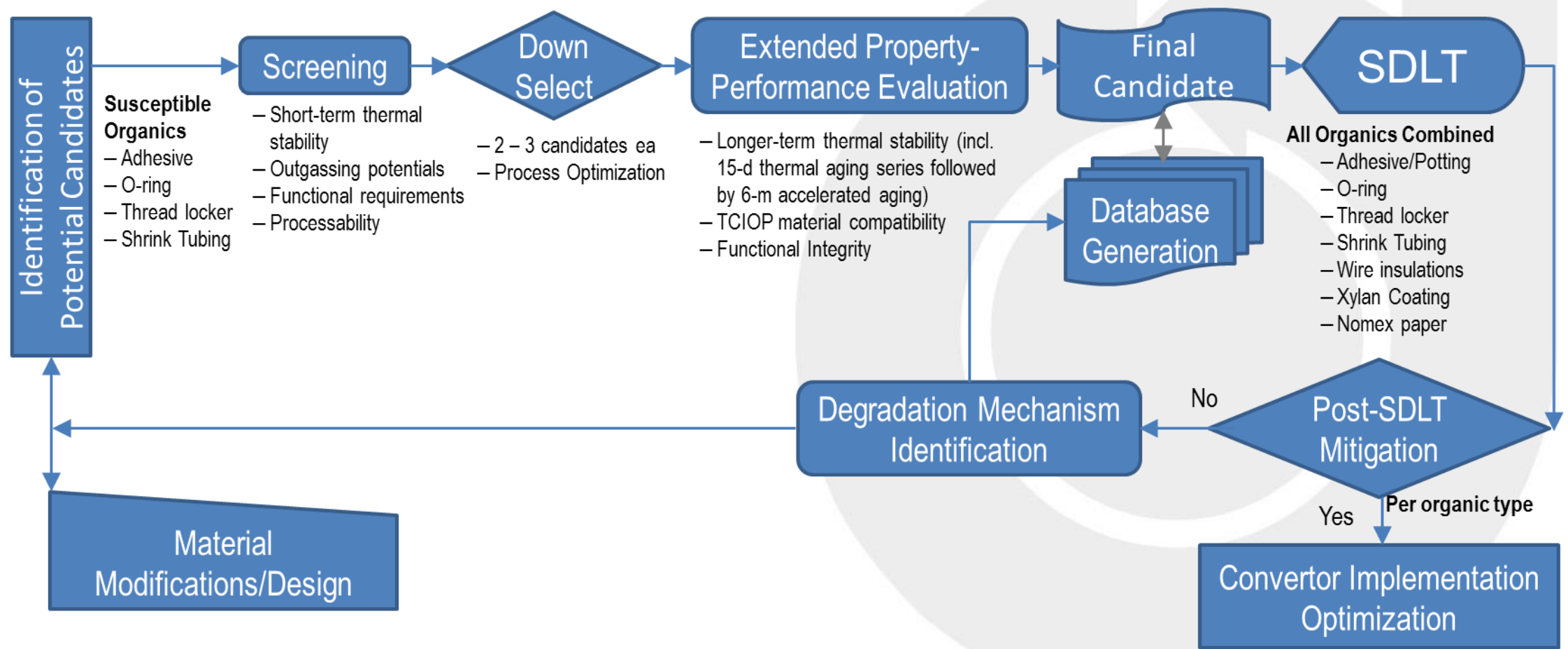

- The initial efforts focused on the most susceptible organics $\rightarrow$ the plan completed up to the "Final Candidate" step as of today 


\section{Materials and Processes}

\section{Candidate materials investigated, all commercially available}

\begin{tabular}{|c|c|c|c|c|c|}
\hline $\begin{array}{l}\text { Material } \\
\text { Class }\end{array}$ & Brand & Maker & $\begin{array}{c}\text { Max. T } \\
{ }^{\circ} \mathrm{C}\end{array}$ & $\begin{array}{c}\text { Install T } \\
{ }^{\circ} \mathrm{C}\end{array}$ & Product properties \\
\hline \multicolumn{6}{|c|}{ Adhesive/ Potting Candidadates } \\
\hline Epoxy & \begin{tabular}{|l|} 
Hysol \\
EA9394 \\
C-2 \\
\end{tabular} & Henkel & 232 & $93 / 115$ & $\begin{array}{l}\text { Two part epoxy paste filled with aluminum } \\
\text { particle; long pot-life ( } 8 \text { hours at } 25^{\circ} \mathrm{C} \text { ) }\end{array}$ \\
\hline \multirow{2}{*}{$\begin{array}{l}\text { Cyanate } \\
\text { ester }\end{array}$} & FM2555 & Cytec & 232 & $177 / 227$ & $\begin{array}{l}\text { Supported film adhesive on structural } \\
\text { carrier; } 0.06 \text { psf film }\end{array}$ \\
\hline & RS-4A & YLA & & 177 & Unsupported film adhesive; 0.03 psf film \\
\hline Epoxy & L-313U & JD Lincoln & 204 & $135 / 213$ & Unsupported film adhesive; 0.05 psf film \\
\hline \multirow{2}{*}{ Epoxy } & \multirow{2}{*}{$\begin{array}{l}\text { AF191K } \\
\text { AF191U }\end{array}$} & \multirow{2}{*}{$3 \mathrm{M}$} & \multirow{2}{*}{204} & \multirow{2}{*}{$177 / 204$} & Supported (0.08 psf) or \\
\hline & & & & & unsupported ( $0.055 \mathrm{psf}$ ) flm adhesive \\
\hline Epoxy & AF131-2 & $3 \mathrm{M}$ & 232 & 177 & $\begin{array}{l}\text { Flexible scrim supported film adhesive, } \\
0.075 \mathrm{psf}\end{array}$ \\
\hline \multicolumn{6}{|c|}{ Thread Locker Candidates } \\
\hline \multirow{2}{*}{$\begin{array}{l}\text { Dimethacryl } \\
\text { ate ester }\end{array}$} & Loctite 266 & Henkel & 232 & $25-40$ & $\begin{array}{l}\text { One part, surface insensitive, high strength, } \\
\text { high temperature anaerobic material }\end{array}$ \\
\hline & Loctite 294 & Henkel & 204 & $25-40$ & $\begin{array}{l}\text { One part, low viscosity, high temperature } \\
\text { anaerobic locking and sealing material }\end{array}$ \\
\hline Epoxy & $\begin{array}{l}\text { Resbond } \\
\text { 507TS }\end{array}$ & Cotronics & 260 & 25 & $\begin{array}{l}\text { Two parts epoxy-based thread locker \& } \\
\text { sealant, filled with PTFE particle for lubricity }\end{array}$ \\
\hline Ceramic & $\begin{array}{l}\text { Resbond } \\
\text { 907TS } \\
\end{array}$ & Cotronics & 1148 & $25 / 121$ & $\begin{array}{l}\text { Water-based proprietary material, cured } \\
\text { by moisture removal }\end{array}$ \\
\hline PET & $\begin{array}{l}\text { Poly-Lok } \\
\text { Patch }\end{array}$ & $\begin{array}{l}\text { Long-Lok } \\
\text { Fasteners }\end{array}$ & 204 & 25 & $\begin{array}{l}\text { Solidified plastic locker patched on fastener } \\
\text { at predetermined locations with optimum } \\
\text { amount }\end{array}$ \\
\hline
\end{tabular}

\begin{tabular}{|c|c|c|c|c|c|}
\hline $\begin{array}{c}\text { Material } \\
\text { Class }\end{array}$ & Brand & Maker & $\begin{array}{c}\text { Max. T } \\
{ }^{\circ} \mathrm{C} \\
\end{array}$ & $\begin{array}{c}\text { Install T } \\
{ }^{\circ} \mathrm{C}\end{array}$ & Product properties \\
\hline \multicolumn{6}{|c|}{ Shrink Tubing Candidates } \\
\hline Polyimide & $208 X$ & Dunstone & $\begin{array}{l}220- \\
400\end{array}$ & 350 & $\begin{array}{l}\text { Shrink ratio > 1.12:1; highest temperature } \\
\text { shrinkable film commercially available }\end{array}$ \\
\hline PEEK & PEEK & ZEUS & 260 & 330 & $\begin{array}{l}\text { Shrink ratio > 1.4:1; excellent abrasion } \\
\text { resistance and radiation resistance }\end{array}$ \\
\hline $\begin{array}{l}\text { Teflon } \\
\text { copolymer }\end{array}$ & PFA & ZEUS & 260 & 340 & $\begin{array}{l}\text { Shrink ratio }>1.4: 1 \text {; improved thermal } \\
\text { stability and radiation resistance }\end{array}$ \\
\hline ETFE & RT-555 & Raychem & 200 & 220 & $\begin{array}{l}\text { Shrink ratio > 2:1; extremely resistant to } \\
\text { hydrocarbons, low outgassing }\end{array}$ \\
\hline Silicone & SRFR & Raychem & 200 & 175 & Shrink ratio > 1.5:1; extremely flexible \\
\hline \multicolumn{6}{|c|}{ 0-ring Candidates } \\
\hline \multirow[t]{2}{*}{ Silicone } & 70SLR & Marco & 200 & n/a & $\begin{array}{l}\text { Baseline material for current SOA } \\
\text { convertors }\end{array}$ \\
\hline & $S 1151$ & Marco & 315 & n/a & High temperature formulation \\
\hline \multirow{3}{*}{\begin{tabular}{|l|} 
Perfluoro- \\
elastomer/ \\
Fluoro- \\
carbon \\
Rubber \\
(FFKM)
\end{tabular}} & Kalrez & DuPont & 260 & n/a & $\begin{array}{l}\text { Excellent chemical and temperature } \\
\text { resistance }\end{array}$ \\
\hline & $\begin{array}{l}\text { Markez } \\
\text { Z1028 }\end{array}$ & Marco & 300 & n/a & $\begin{array}{l}\text { Black, excellent chemical compatbility and } \\
\text { high temperature capabilities }\end{array}$ \\
\hline & $\begin{array}{l}\text { Markez } \\
\text { Z1307 }\end{array}$ & Marco & 275 & n/a & $\begin{array}{l}\text { Translucent, semi-crystalline nano-filled; } \\
\text { low out-gassing; high temp capabilities }\end{array}$ \\
\hline
\end{tabular}




\section{Materials and Processes, Cont'd}

- Adhesive/potting candidates

- Processed in a hot press or autoclave after conventional vacuum-bagging

- Initial cure conditions per manufacturer's recommendations $\rightarrow$ optimized for final

- Optimum mixing in a Thinky mixer for two part systems

- Various sheet samples: thick ( $1.5 \mathrm{~mm})$ to mimic the potting; thin $(\sim 0.1 \mathrm{~mm})$ or the thin sample but laminated between metal substrate to mimic bonding

- Thread locker candidates

- Cure conditions optimized during initial screening evaluations

- Shrink tubing candidates

- 3/16" OD - 1.12" (30 mm) long sections; shrunk snugly without metal core

- O-ring candidates

- Nominal, 7/16" ID - 9/16" OD - 1/16" CS (Actual, 0.426" ID - 0.070" CS) 


\section{Experimental: Material Property Testing}

- Extensive and systematic material property characterizations (i) to compare candidates and (ii) to identify the degree of degradation and its mechanisms as a function of exposure conditions:

- Physical properties, e.g., weight, dimensions, color, and surface microstructures

- Thermal properties $T_{m}, T_{g}, T_{\beta}, T_{r}, T_{t}, T_{\text {end }}, T_{\text {exo }}, \Delta H, \Delta W t \%, G^{\prime}, G^{\prime \prime}$, and \% cure via mDSC, TGA, and DMA or TMA;

- Other outgassing characteristics by isothermal TGA analysis, typically at 120 , 150 , or $200^{\circ} \mathrm{C}$ for 7 hours: initial wt loss, dwell wt loss, and wt loss rate at the last 100 minutes related to ASTM outgassing database

- Molecular/chemical structural properties via FT-IR spectral analyses 


\section{Material Property Testing, Cont'd}

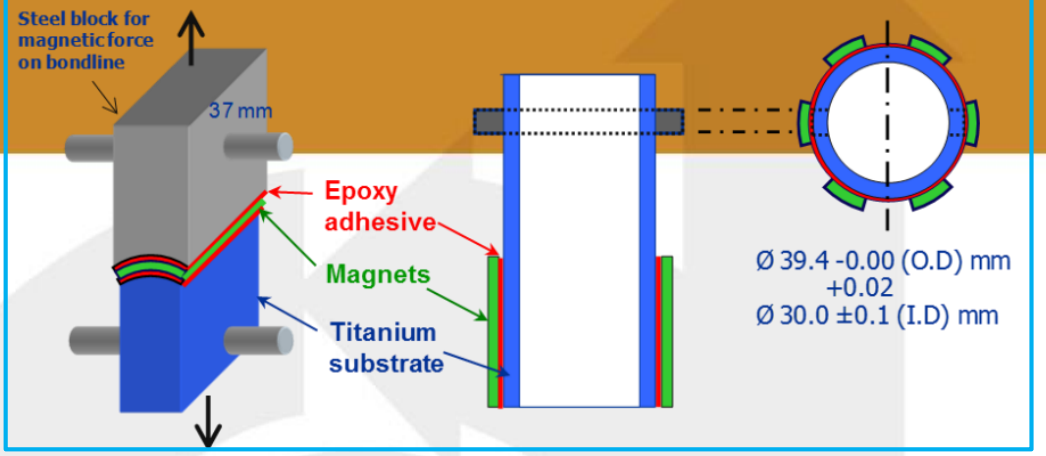

- Adhesive: bonding integrity in shear and FWT mode using either component-level full-scale or subscale sandwich lap shear specimens for both static and fatigue loading modes,

- Thread locker: torque strengths in $\underline{3-4}$ representative joint types using the same materials, same dimensions, and configurations (esp. thru-hole vs. blind-hole) as the actual convertor components, based on the BS EN 15865 Standard,

- Shrink tubing: notched tensile properties, in both axial and radial directions

- O-ring: compression-set; hardness; tensile properties followed by the ASTM standards, D395, Method B; D2240, Shore A scale; D1414, Method B, respectively
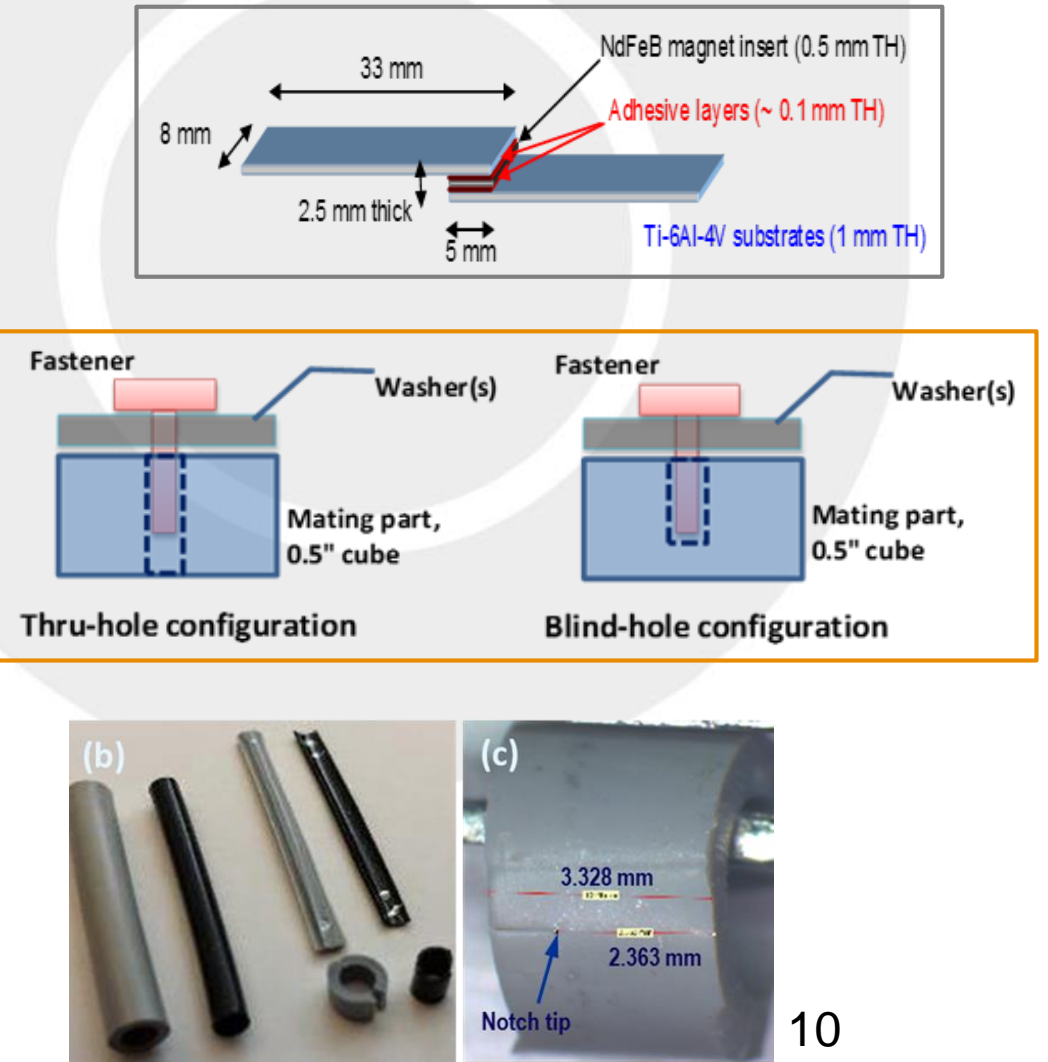


\section{OpIna}

\section{Experimental: Thermal Aging}

- SOP for start-up \& shut-down

- Inert gas environment, $\mathrm{N}_{2}$ gas

- Temperature \& gas flow rate monitored and adjusted daily

- 15-day thermal aging up to $260^{\circ} \mathrm{C}$

- Two phases at 4 temperature ea.

- 6-month accelerated aging

- Adhesive, shrink tubing, and o-ring candidates run together at 175,200 , and $225^{\circ} \mathrm{C}$

- Thread locker at 190 and $220^{\circ} \mathrm{C}$
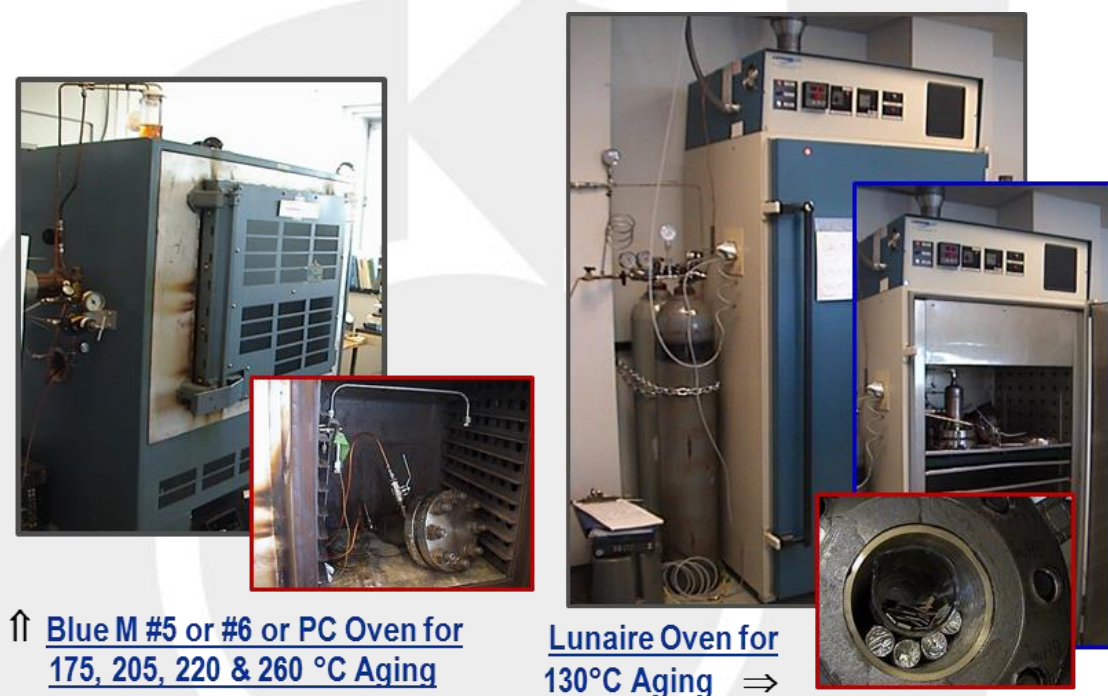

$\frac{\text { Blue } \mathrm{M} \# 5 \text { or } \# 6 \text { or PC Oven for }}{175,205,220 \& 260^{\circ} \mathrm{C} \text { Aging }}$

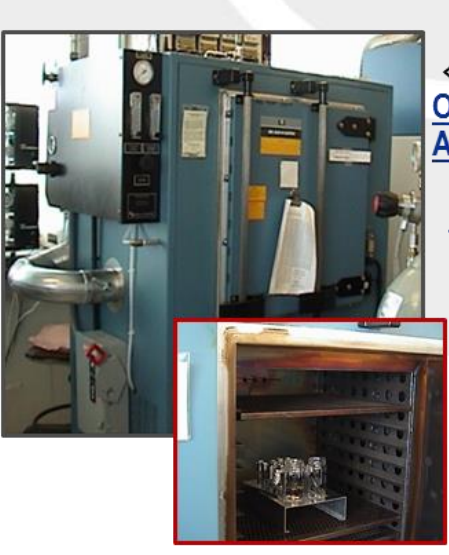

$130^{\circ} \mathrm{C}$ Aging $\Rightarrow$

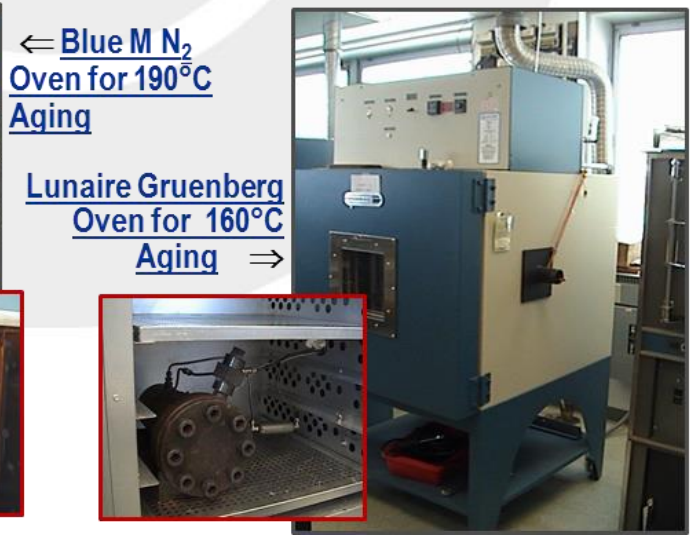




\section{Experimental: TCIOP Testing}

Integrated RGA-GC/TCD-MS-FTIR gas analysis system

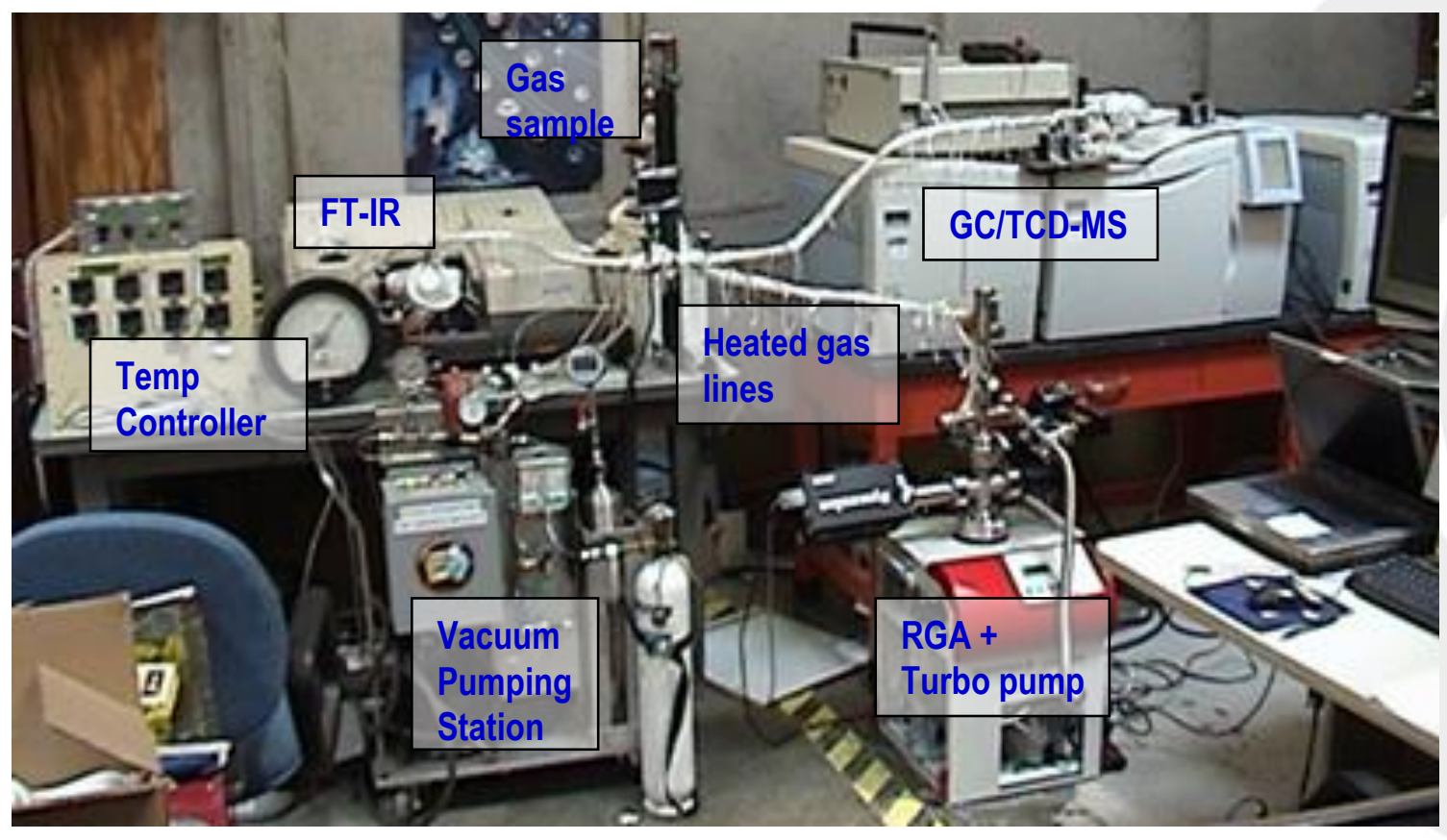

- Systematic residual property characterizations of the TCIOP exposed samples $\rightarrow$ outgas-induced degradation and its mechanisms

\section{Standardized test procedure:}

1. loaded samples into PV, pulled vacuum

2. baked @ $90{ }^{\circ} \mathrm{C}$ for 1 day under vacuum

3. charged with the pre-mixed gas, typical Stirling gas sample, to 400 psi @ RT

4. leak-checked for 1 day

5. analyzed gas sample @ RT by all

6. heated to $100^{\circ} \mathrm{C}$; dwelled 3 days

7. heated to $150^{\circ} \mathrm{C}$; dwelled 2 days

8. heated to $200^{\circ} \mathrm{C}$; dwelled 7 days

- heating rate @ $1^{\circ} \mathrm{C} / \mathrm{min}$

- during heating, outgas analysis only by FT-IR every 20 min

- during dwell, outgas analyses by all per day

Pre-mix gas: $107 \mathrm{ppm} \mathrm{H}_{2}, 1,060 \mathrm{ppm} \mathrm{O}_{2}, 3,081 \mathrm{ppm} \mathrm{N}, 312 \mathrm{ppm} \mathrm{CO}_{2}$ in balance of $\mathrm{He}$ 


\section{Results \& Discussions: Initial Screening and Down-selection}

Overall ratings of adhesive/potting candidates

\begin{tabular}{|c|c|c|c|c|c|c|}
\hline \begin{tabular}{|l|l|} 
Properties & Material type \\
\end{tabular} & $\mathrm{L}-313$ & RS-4A & F M2555 & AF 131-2 & AF $191 K$ & EA9394C-2 \\
\hline Cure Condition & - & - & - & - & - & + \\
\hline Processability/Applicability & 0 & - & - & 0 & 0 & + \\
\hline Multi-purpose Application & + & - & - & - & - & + \\
\hline Thermal Degradation Temperatu re/TGA & + & + & + & + & + & + \\
\hline Weight loss/outgssing potential & - & & & + & 0 & 0 \\
\hline Thermal Transisiton $/ \mathrm{mD} \mathrm{SC}$ & 0 & 0 & 0 & 0 & 0 & 0 \\
\hline Shear Bond Strength & + & - & - & + & + & + \\
\hline FWT Bond Strength & - & & & + & & + \\
\hline F inal Selection & & & & $\checkmark$ & & $\checkmark$ \\
\hline
\end{tabular}

Note: 0, neu tral or insig nificant effect; + , positive perfo mance;, negative perfo mance

\section{Overall ratings of thread locker candidates}

\begin{tabular}{|c|c|c|c|c|}
\hline $\begin{array}{lr}\text { Properties } & \text { Material type } \\
\end{array}$ & Loctite 266 & Loctite 294 & Resbond 507 TS & Resbond 907TS \\
\hline Cure Condition & + & + & + & + \\
\hline Processability & 0 & $\mathbf{0}$ & 0 & 0 \\
\hline FT-IR @ RT & 0 & 0 & 0 & 0 \\
\hline Thermal Degradation Temperature/TGA & + & + & + & + \\
\hline Weight loss/outgssing potential/iso-TGA & 0 & 0 & + & - \\
\hline Thermal Transis iton/mDSC & 0 & 0 & 0 & 0 \\
\hline Breakaway Torque & 0 & 0 & + & + \\
\hline Max. Prevailing Torque & - & + & + & 0 \\
\hline Final Selection & & $\checkmark$ & $\checkmark$ & \\
\hline
\end{tabular}

Note: 0 , neutral or insignificant effect; +, positive performance; -, negative performance
Superior thermal performance and stability for AF131-2

- Best multi-purpose system and large supportive database from the basic formulation, EA9394, for EA9394C-2
- Torque strength tested on M10 steel nuts \& bolts at RT as a function of cure conditions

- Poly-Lok PET was also selected as an alternative because of its potential as a solid patch system 


\section{Results \& Discussions: Initial Screening and Down-selection}

Overall ratings of shrink tubing candidates

\begin{tabular}{|c|c|c|c|c|c|c|}
\hline Material type & Viton $(\alpha)$ & PFA & SRFR & ETFE & PEEK & PI \\
\hline Shrinking Temperature & + & + & + & + & - & - \\
\hline Shrinking Ratio & + & - & + & + & - & - \\
\hline FT-IR @ RT: on both OD and ID & 0 & 0 & 0 & 0 & 0 & 0 \\
\hline Thermal Degradation Temperature/TGA & + & + & + & + & + & + \\
\hline Weight loss/outgssing potential/iso-TGA & + & + & + & + & - & - \\
\hline Thermal Transisiton/mDSC & 0 & 0 & 0 & 0 & 0 & 0 \\
\hline \multirow{2}{*}{$\begin{array}{l}\text { Modulus-Drop Ratio } \\
\text { at Temperature/D MA }\end{array}$} & - & - & 0 & 0 & + & + \\
\hline & - & - & 0 & 0 & + & + \\
\hline Notched Tensile strength: Axial & - & 0 & 0 & 0 & + & + \\
\hline Notched Tensile strength: Radial & - & 0 & 0 & 0 & + & + \\
\hline Final Selection & & & $\checkmark$ & $\checkmark$ & & \\
\hline
\end{tabular}

- Shrinking process conditions optimized for each candidate

- Final candidates selected with less negative performance, thus need more thorough extended evaluations

Overall ratings of o-ring candidates

\begin{tabular}{|c|c|c|c|c|c|}
\hline \begin{tabular}{|ll} 
& O-ring type \\
\end{tabular} & 70SLR & S1151 & Kalrez & Z1028 & Z1307 \\
\hline FT-IR & $\mathbf{0}$ & 0 & $\mathbf{0}$ & 0 & 0 \\
\hline mDSC/DSC - Thermal transitions & 0 & $\mathbf{0}$ & $\mathbf{0}$ & $\mathbf{0}$ & 0 \\
\hline TGA - Thermal degradation onset & + & + & + & + & + \\
\hline TGA \& Iso-TGA - Outgassing potential & - & - & + & + & + \\
\hline DMA - Compression Storage Modulus & 0 & + & + & + & - \\
\hline Compression-set & 0 & 0 & 0 & + & + \\
\hline \multirow{4}{*}{\begin{tabular}{|lc} 
Tensile properties: & $\begin{array}{r}\text { Modulus } \\
\text { Tensile stren } \\
\text { Ultimate elongat }\end{array}$ \\
Max use Temp by Manufacturer \\
\end{tabular}} & 0 & + & - & - & - \\
\hline & 0 & 0 & - & + & - \\
\hline & 0 & $\mathbf{0}$ & $\mathbf{0}$ & $\mathbf{0}$ & $\mathbf{0}$ \\
\hline & 0 & + & + & + & + \\
\hline Final Selection & & $\checkmark$ & & $\checkmark$ & \\
\hline
\end{tabular}




\section{Extended Evaluations: Functional Performance}

- Adhesive for magnet bonding identified as the most critical organic for the Stirling convertor due to its single point failure reliability assessment

- Extensive cure kinetics-\% cure-property relations ascertained for optimizing cure conditions

- investigated broad cure/postcure temperature-time conditions including the results from both 15-day thermal aging and 6-month accelerated thermal aging tests,

- targeted the degree of cure higher than $99.5 \%$

- identified under-cured state or thermal degradation via. systematic property characterizations

$\rightarrow$ The optimum conditions typically required higher cure temperatures or much longer cure time than the manufacturer's recommended conditions.

$\rightarrow$ Increasing the postcure temperature to $190-205^{\circ} \mathrm{C}$ for up to 360 hours improved thermal stability of both candidates. 


\section{Extended Evaluations: Functional Performance}

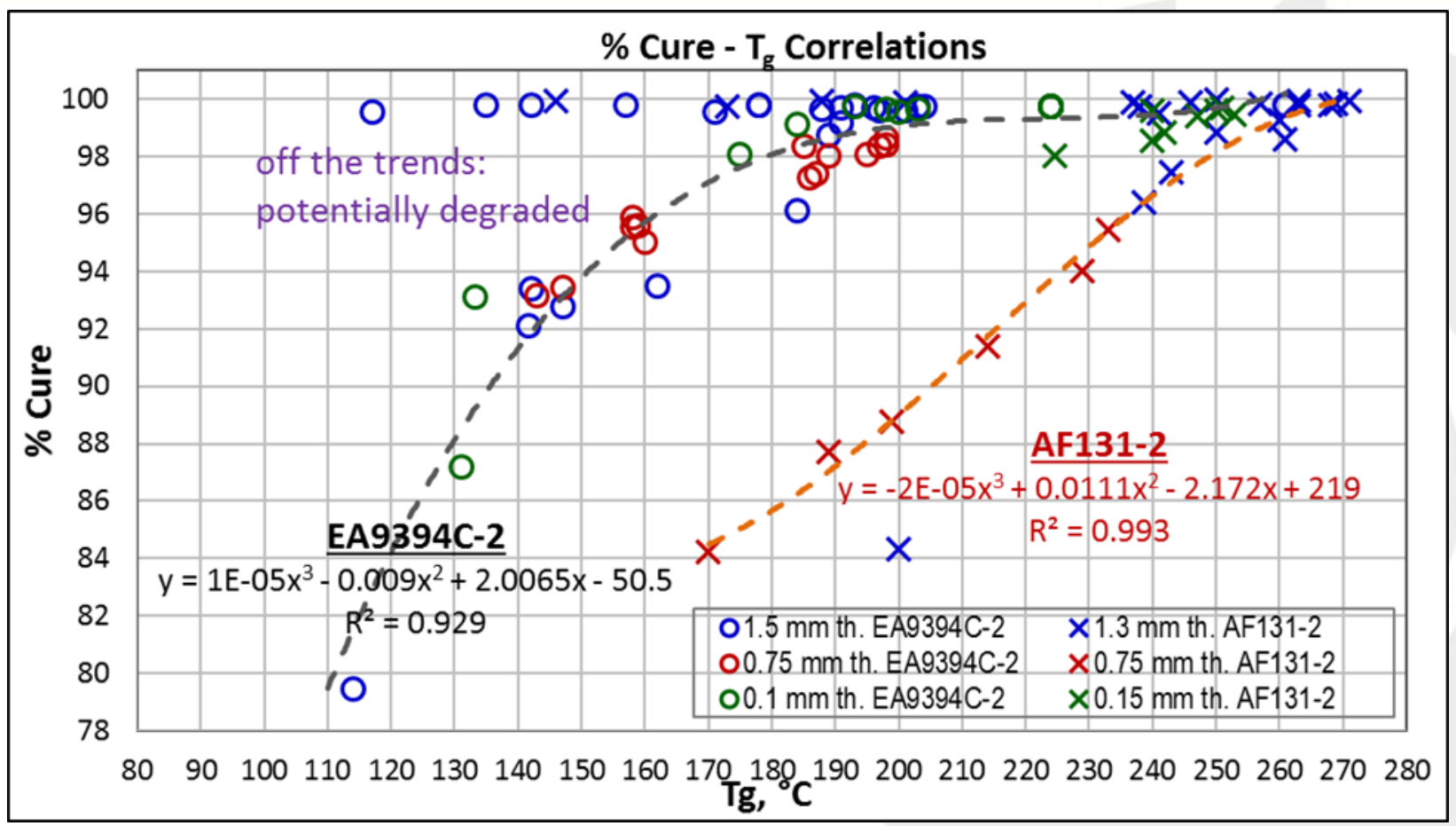

$\checkmark$ Distinctive $\%$ cure- $T_{g}$ correlation regardless of sample thickness $\rightarrow$ used for performance predictions

$\checkmark$ The highest $\mathrm{T}_{\mathrm{g}}$ achieved was fairly close for both adhesive candidates, $260^{\circ} \mathrm{C}$ vs. $270^{\circ} \mathrm{C}$, but nonlinear relationship for EA9394C-2 vs. linear relationship for AF131-2

$\checkmark$ The initial cure conditions determined by the manufacturer's recommendations were acceptable 


\section{Extended Evaluations: Functional Performance}
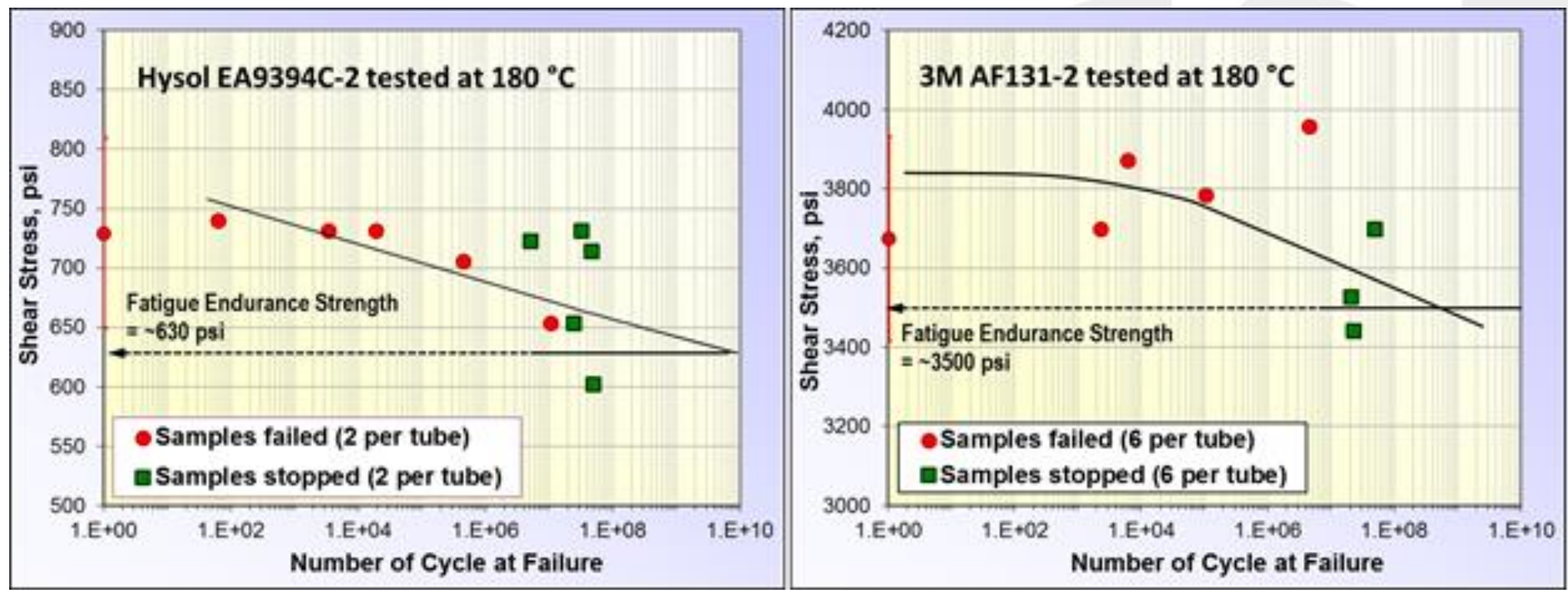

$\checkmark$ Bonding performance via fatigue testing of full-scale component size coupons @ $180{ }^{\circ} \mathrm{C}$

$\checkmark$ AF131-2 outperformed EA9394C-2, but their fatigue strengths were much higher than the theoretical strength needed

$\checkmark$ Fatigue performance of the EA9394C-2 at $180^{\circ} \mathrm{C}$ was comparable to that of the regular EA9394 at $115^{\circ} \mathrm{C}$, i.e., improved thermal stability 


\section{Extended Evaluations: Long-term Thermal Stability}

Long-term performance and thermal stability

$>15$-day thermal aging tests as a function of temperature up to $260^{\circ} \mathrm{C}$

Specific objectives:

- to assess more meaningful but practical short-term thermal stability of downselected candidates and

- to determine the aging mechanism-based maximum temperatures for the 6month accelerated thermal aging tests

$>6$-month accelerated thermal aging tests at $2-3$ temperatures

Specific objectives:

- to assess longer-term thermal stability and integrity for life predictions

- to determine the application limits of the down-selected candidates via extended and systematic property-performance characterizations, and subsequently select the final candidate 


\section{Extended Evaluations: Long-term Thermal Stability}

- From the systematic physical-thermal-chemical-mechanical property characterizations as a function of 15-day aging temperature,

- Good short-term thermal stability up to:

$-220-230^{\circ} \mathrm{C}$ for both adhesives

- $220^{\circ} \mathrm{C}$ for all $\mathrm{TL}$ candidates
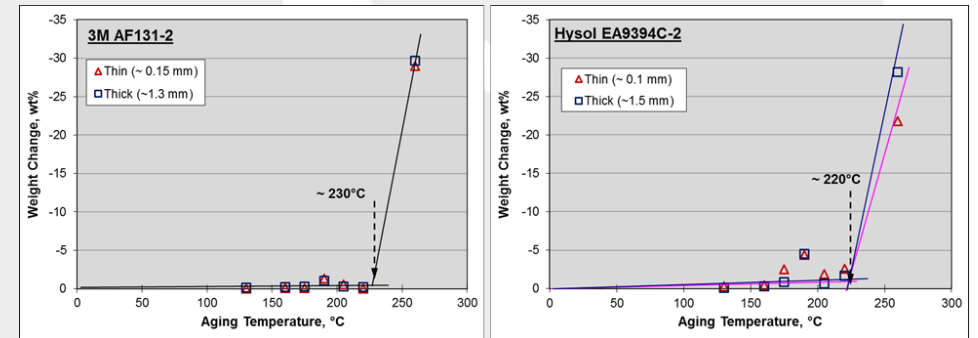

- and a distinctive change in aging mechanism

- $T_{\max }$ for the accelerated aging tests

- 175,200 , and $225^{\circ} \mathrm{C}$ for adhesives, also for shrink tubing and o-ring candidates*

- 190 and $220^{\circ} \mathrm{C}$ for TL candidates

* Not tested due to logistics issues, but based on the initial screening test results, manufacturer's technical data, and max use temperature ratings

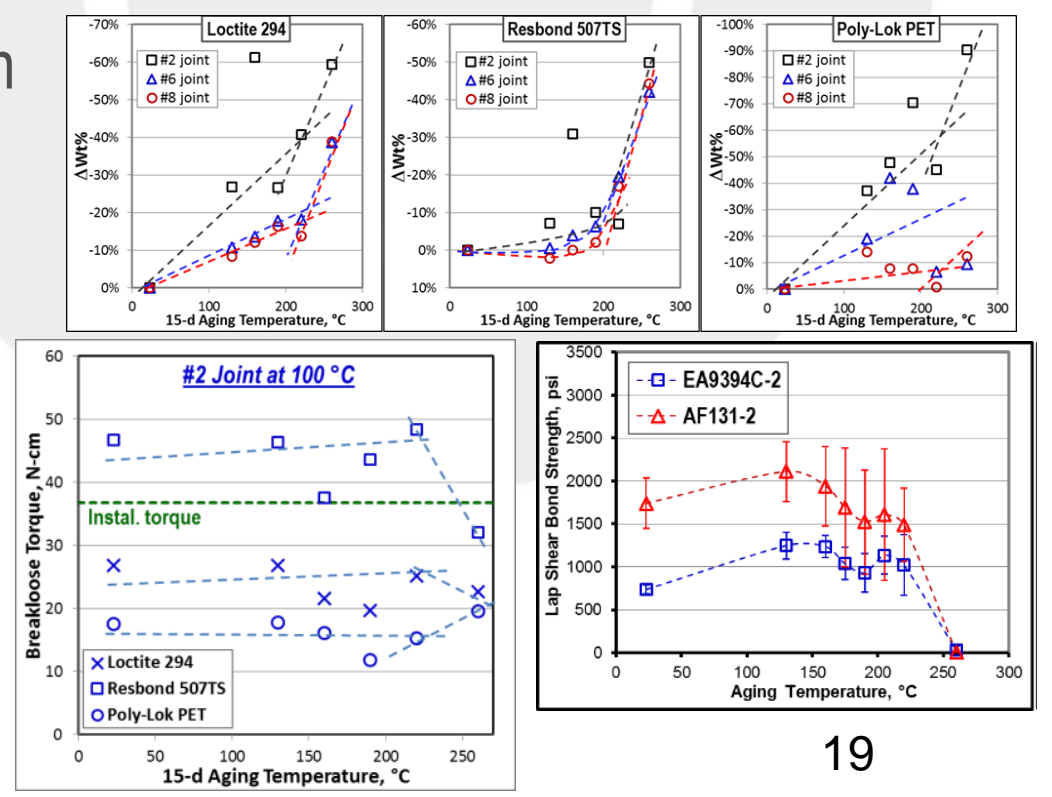




\section{OAIAA}

Shaping the Future of Aerospace

\section{Extended Evaluations: Long-term Thermal Stability}

\section{6-m accelerated aging of adhesives/potting candidates: physical, chemical properties}
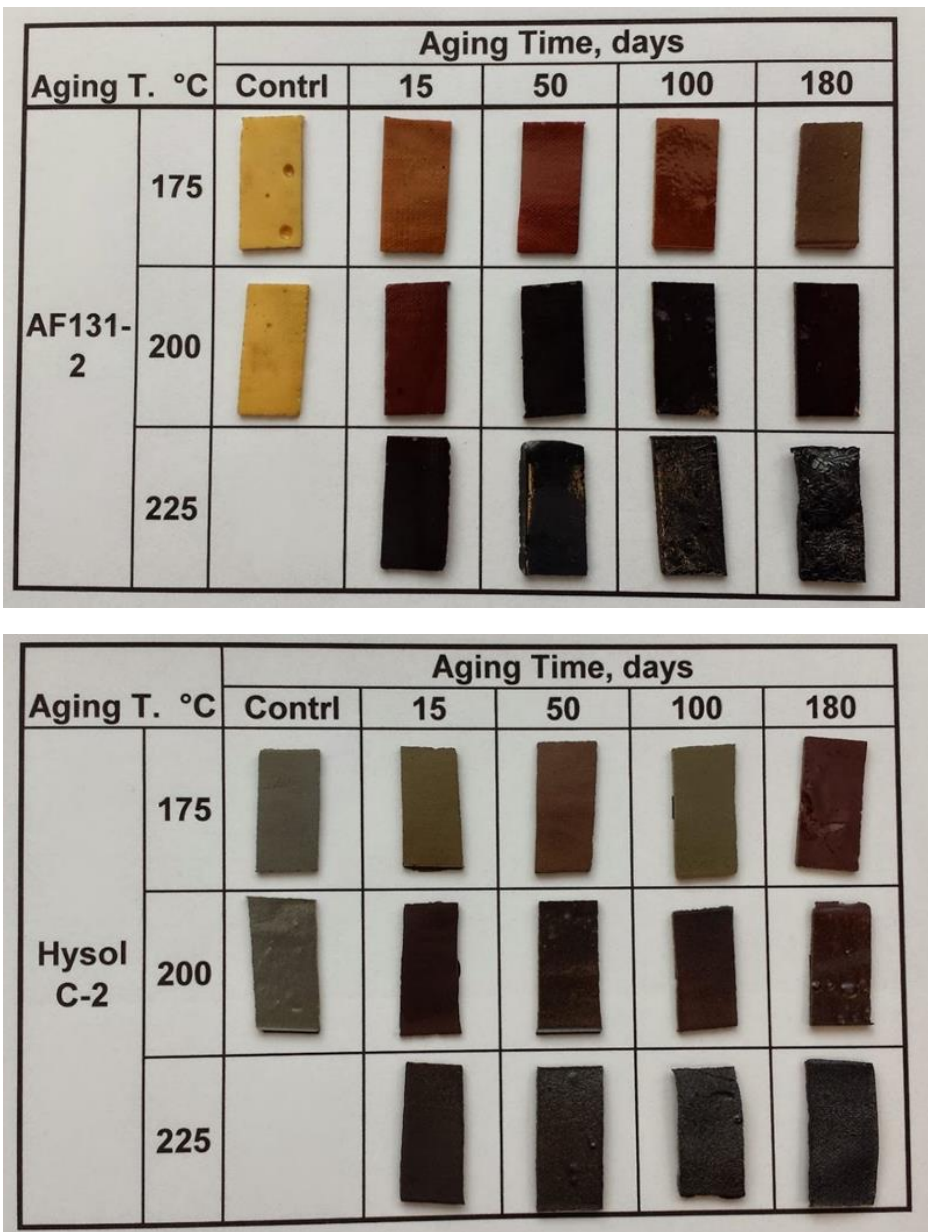
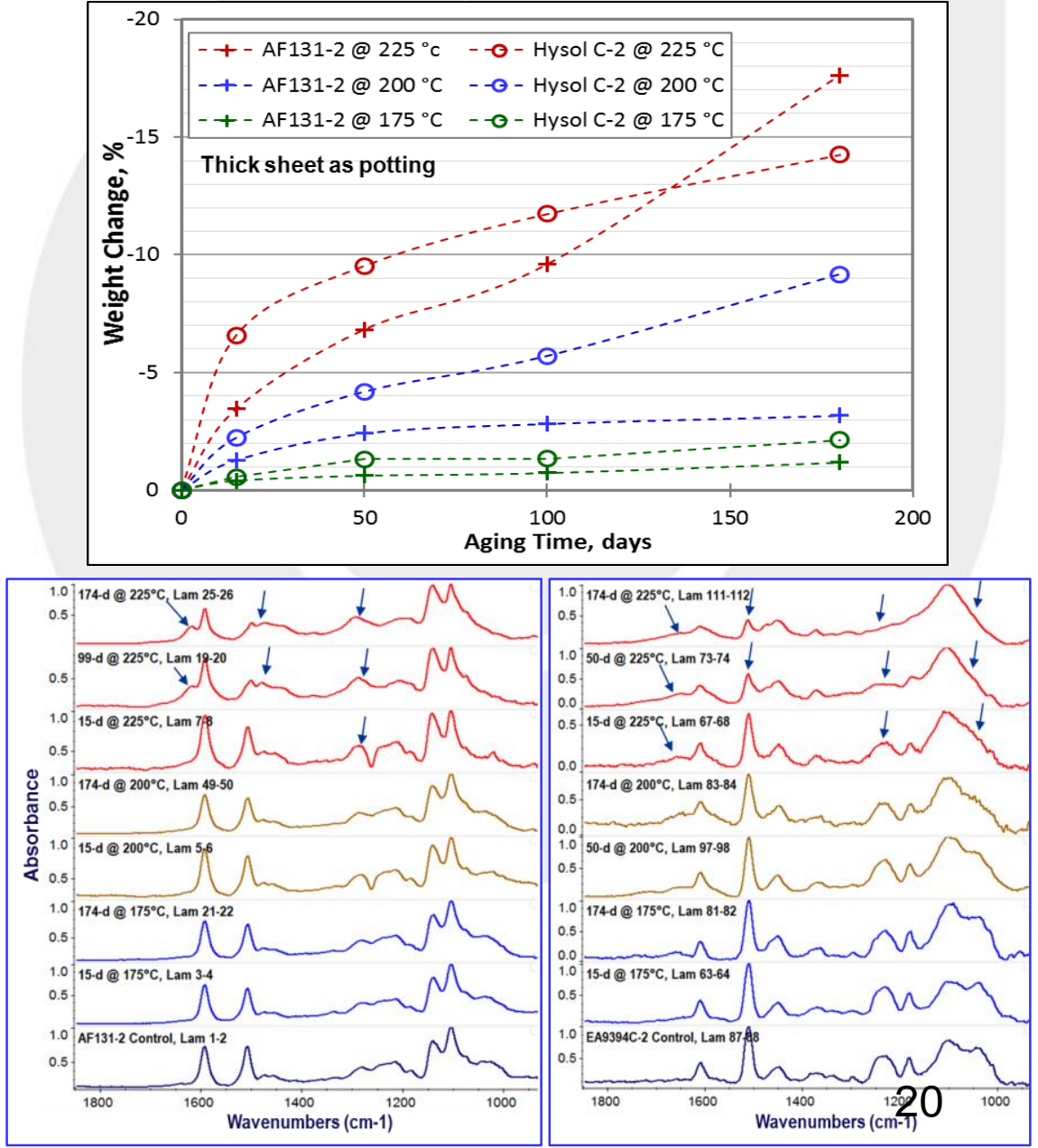


\section{Extended Evaluations: Long-term Thermal Stability}

\section{6-m accelerated aging of adhesives/potting candidates: mechanical properties}
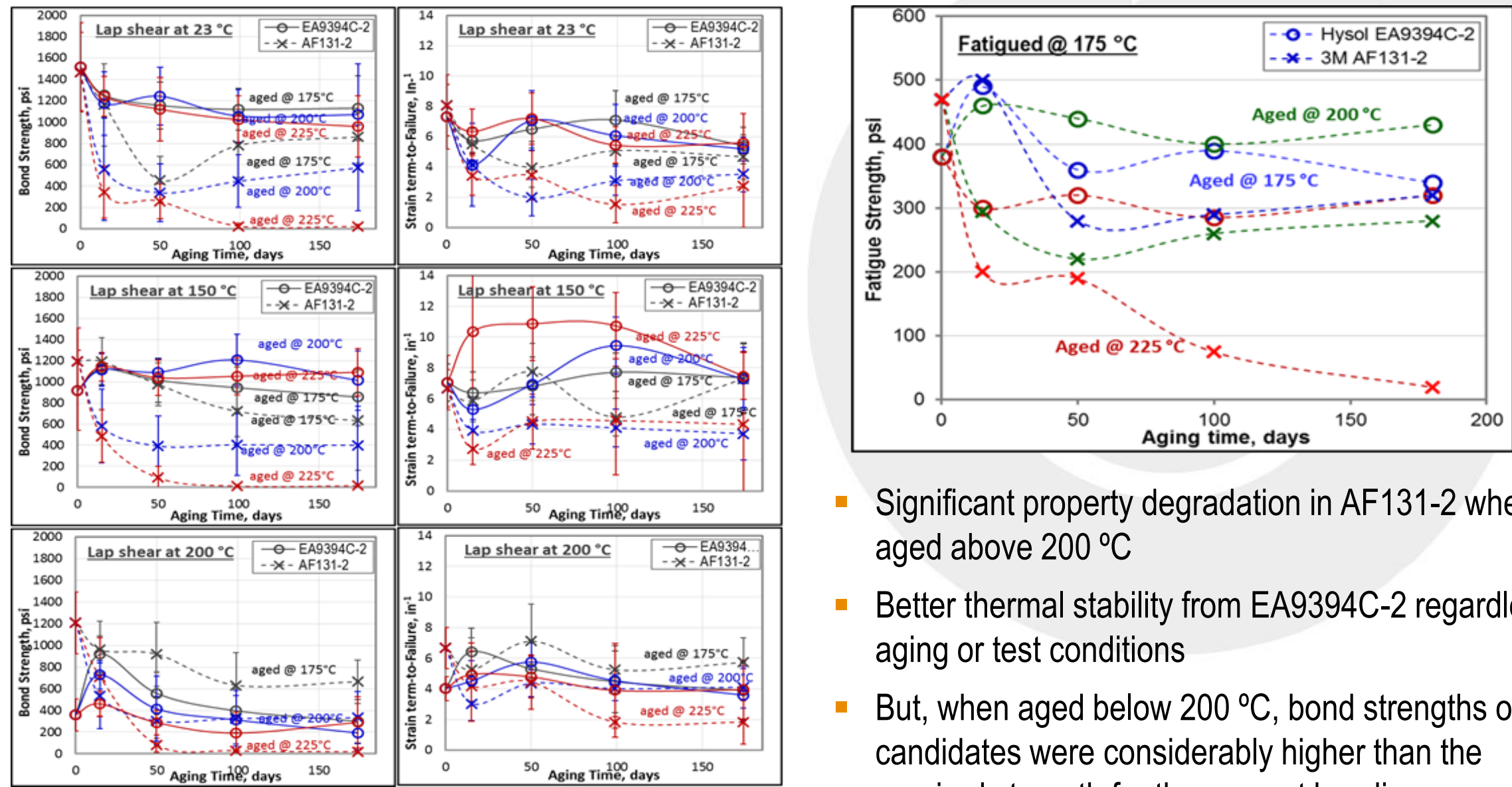

- Significant property degradation in AF131-2 when aged above $200^{\circ} \mathrm{C}$

- Better thermal stability from EA9394C-2 regardless of aging or test conditions

- But, when aged below $200^{\circ} \mathrm{C}$, bond strengths of both candidates were considerably higher than the required strength for the magnet bonding. 


\section{Extended Evaluations: Long-term Thermal Stability}

\section{6-m accelerated aging of adhesives/potting candidates: thermal properties}
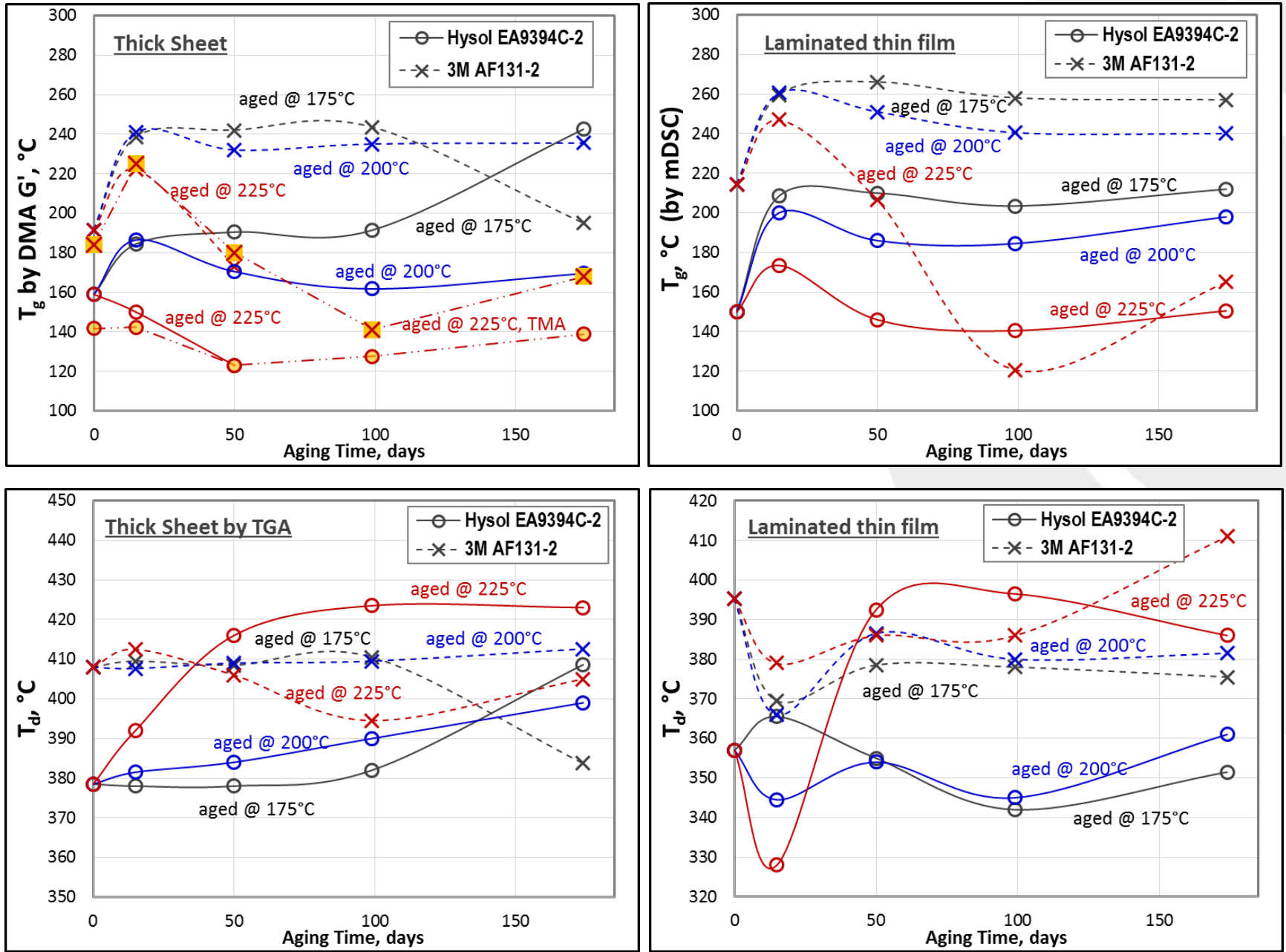

- Most visible property degradation occurred when aged at $225^{\circ} \mathrm{C}$ in both candidates.

- The changes were greater for the AF131-2 in most cases. 


\section{Extended Evaluations: Long-term Thermal Stability}

\section{6-m accelerated aging of adhesives/potting candidates: overall property changes}

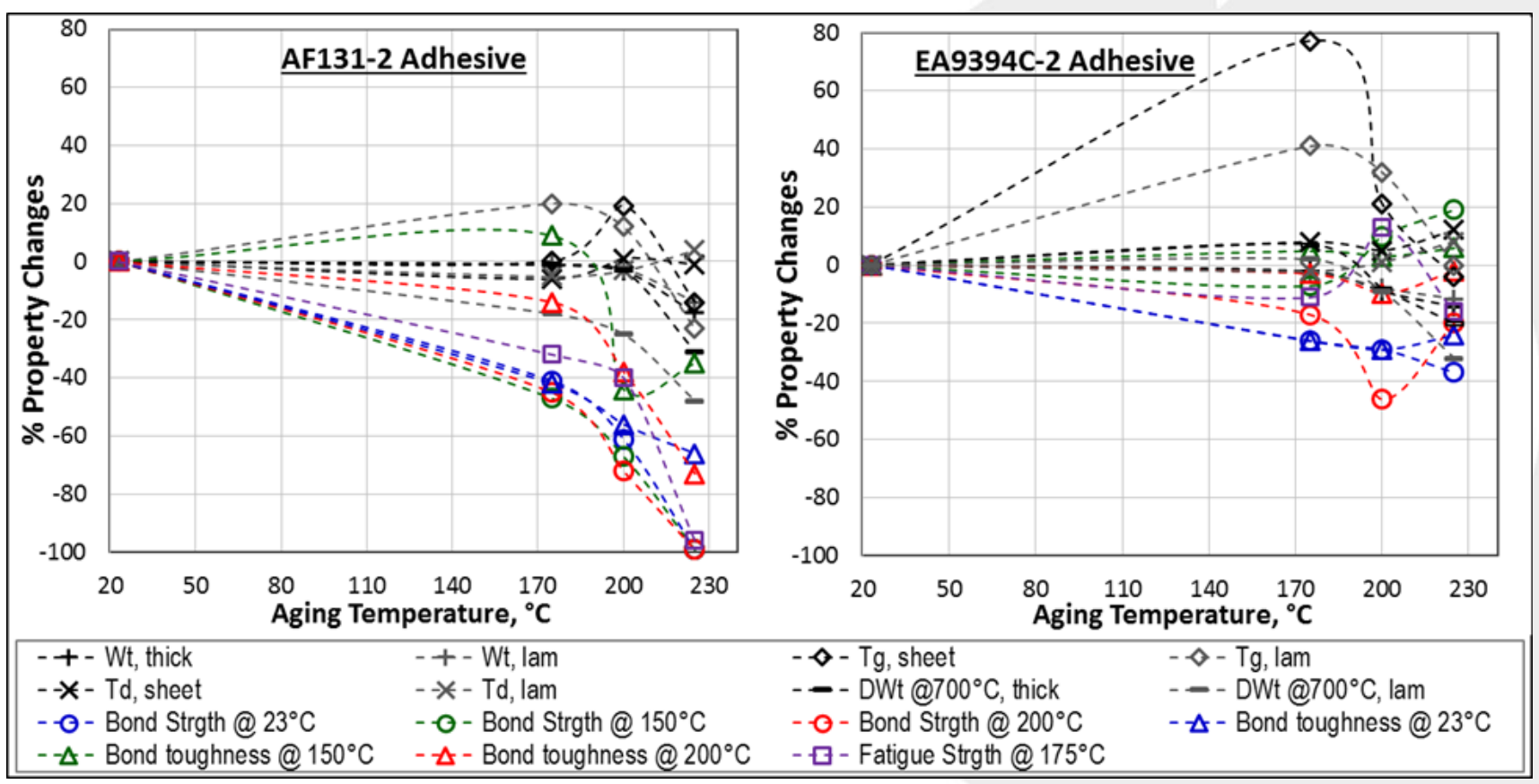

- In most cases, changes in properties leveled-off or stabilized after 180 day regardless of aging T.

- AF131-2 suffered greater reductions in most properties than EA9394C-2, with sharper, more distinctive transitions at $175-200^{\circ} \mathrm{C} \rightarrow$ Better thermal stability from EA9394C-2.

- Larger changes indicate greater effects of the thermal aging, esp., negative changes. 


\section{Extended Evaluations: Long-term Thermal Stability}

\section{6-m accelerated aging of $T L$ candidates: overall property changes}

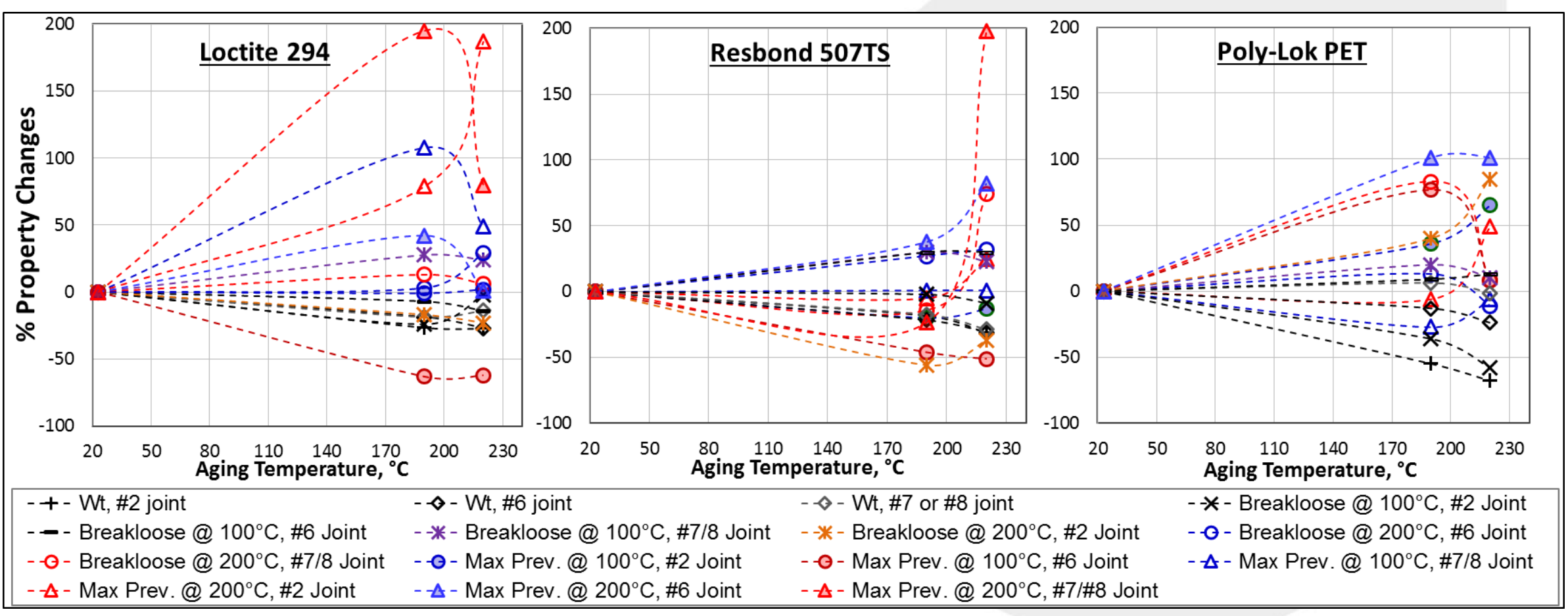

- More positive changes in Loctite 294 and Poly-Lok PET, but better thermal stability from Resbond 507TS 


\section{Extended Evaluations: Long-term Thermal Stability}

\section{6-m accelerated aging of TL candidates: mechanical properties}
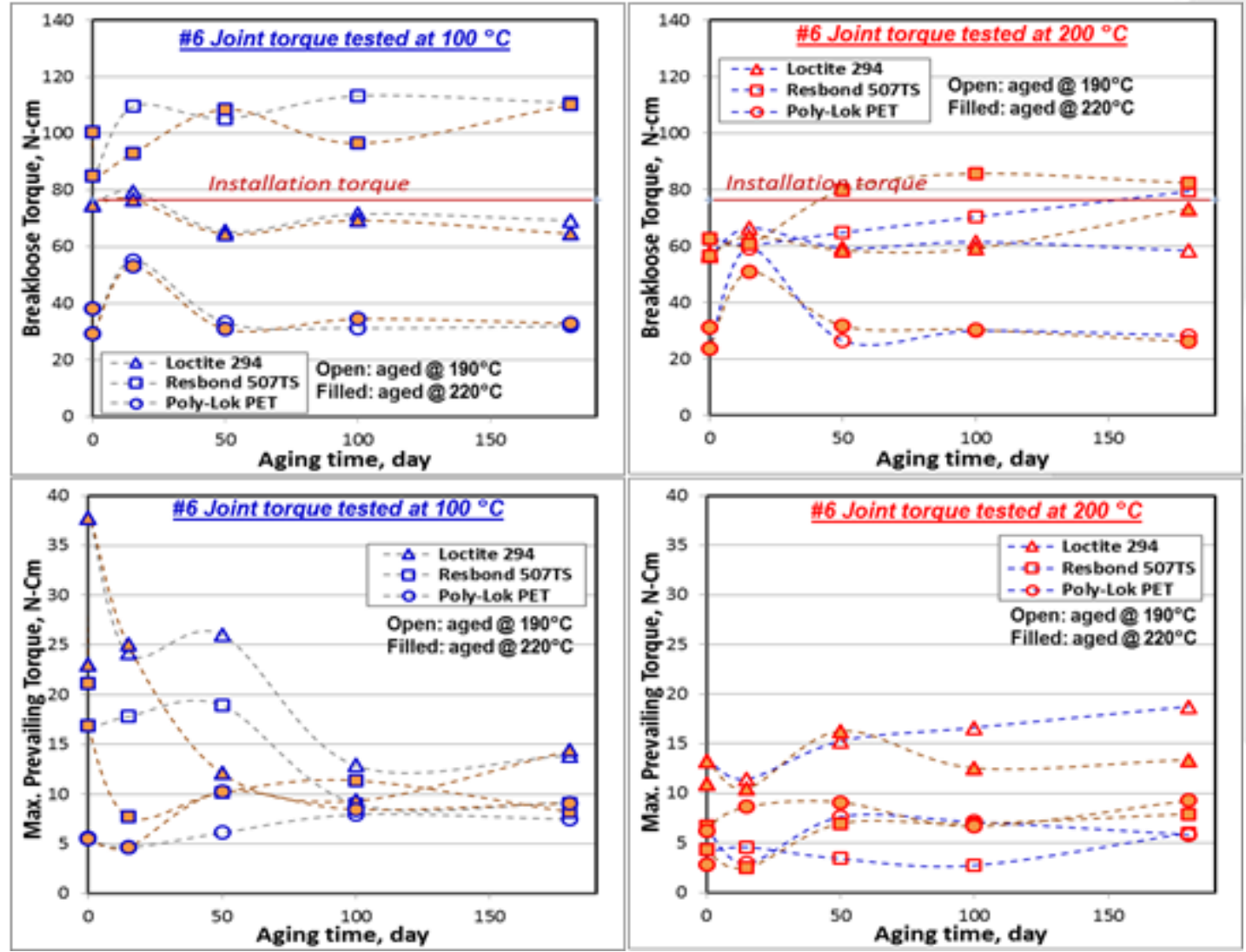

- Resbond 507TS outperformed other candidates regardless of aging condition, joint type, or test temperature.

$\rightarrow$ the only candidate generating $100{ }^{\circ} \mathrm{C}$ breakloose torques greater than the installation torques in all three joint types

- At $200^{\circ} \mathrm{C}$, the Resbond 507TS suffered the most loss of breakloose torque even though its strength was still higher than others. 


\section{Extended Evaluations: Long-term Thermal Stability}

\section{6-m accelerated aging of shrink tubing candidates: overall property changes}

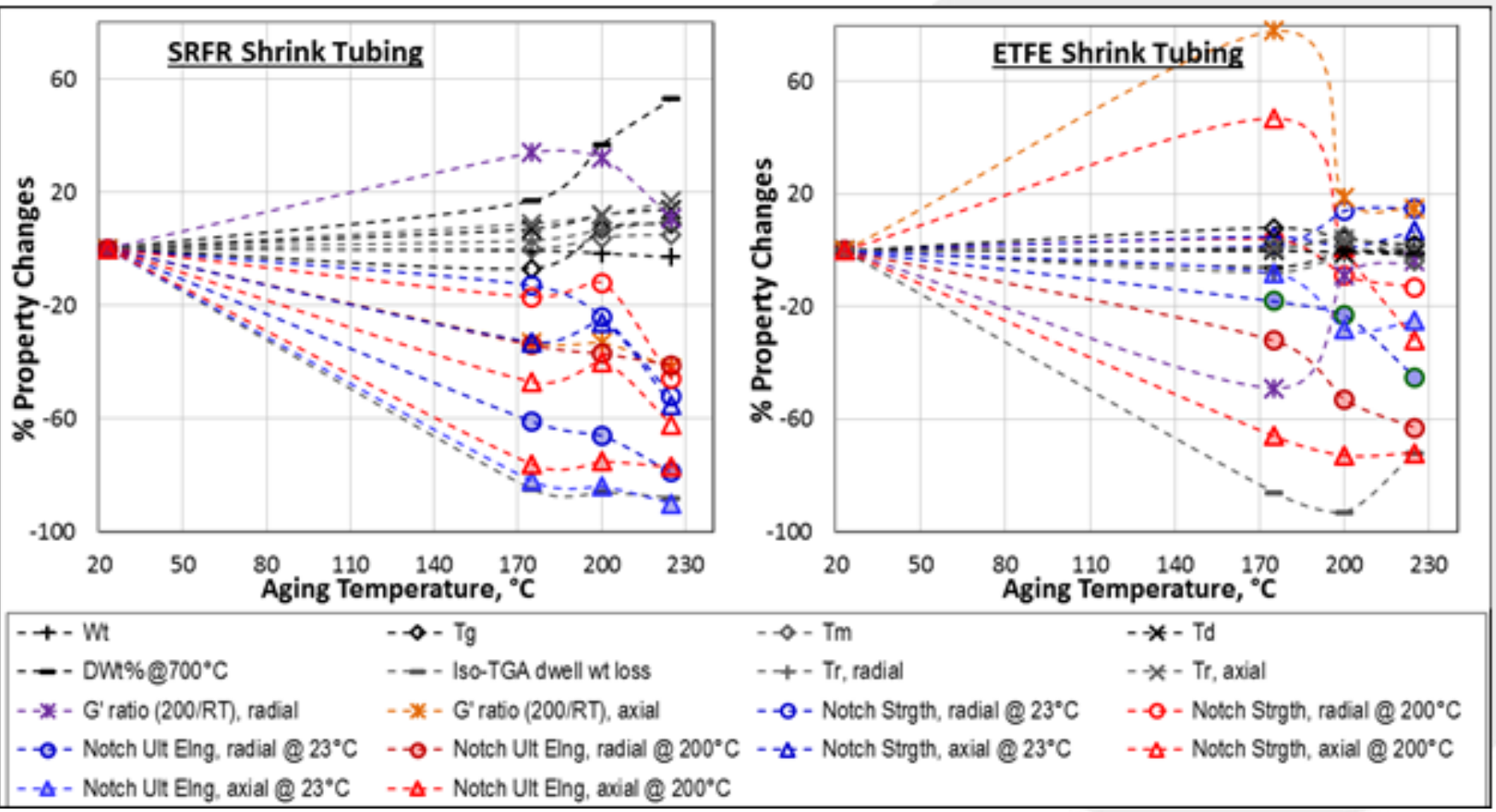

- ETFE performed significantly better in most mechanical properties and more thermally stable than SRFR regardless of sample direction (either axial or radial) and test temperature. 


\section{Extended Evaluations: Long-term Thermal Stability}

\section{6-m accelerated aging of o-ring candidates: overall property changes}

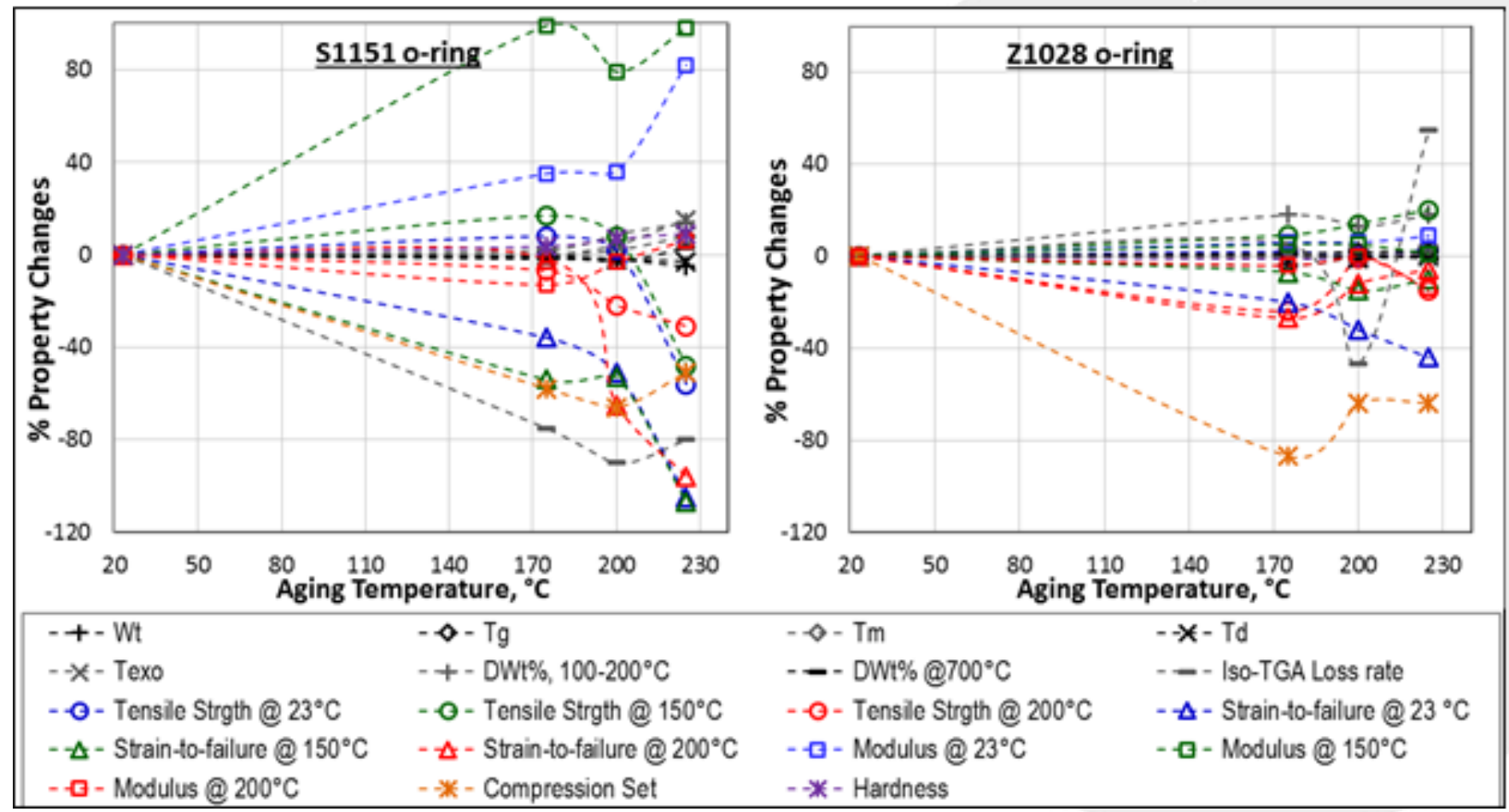

- Overall, Z1028 was more thermally stable than S1151.

- Z1028 outperformed S1151 in most mechanical properties.

- Signs of thermal degradation in $\mathrm{S} 1151$ when aged above $200{ }^{\circ} \mathrm{C}$ 


\section{Extended Evaluations: TCIOP Material Compatibility}

\section{Temperature-alone Combined In-situ Outgassing (TCIO)}

Test with Pre-mix gas

\section{Specific objectives:}

- to determine outgassing behavior of the down-selected candidates under the typical Stirling convertor pre-mix gas environment and its effects on their properties and performance

- to assess material compatibility for the Stirling application.

$\rightarrow$ Material compatibility assessment made with two step process: (i) in-situ outgas analyses and (ii) residual property characterizations 


\section{Extended Evaluations: TCIOP Material Compatibility}

\section{Outgas Analysis Summary}

Pre-mixed gas: $107 \mathrm{ppm} \mathrm{H}_{2}, 1,060 \mathrm{ppm} \mathrm{O}_{2}, 3,081 \mathrm{ppm} \mathrm{N}_{2}, 312 \mathrm{ppm} \mathrm{CO}_{2}$, and the balance of $\mathrm{He}$

\begin{tabular}{|c|c|c|c|c|c|c|c|}
\hline \multirow{2}{*}{\multicolumn{2}{|c|}{$\begin{array}{r}\text { Exposure temperature, }{ }^{\circ} \mathrm{C} \\
\text { Exposure time, day }\end{array}$}} & \multicolumn{2}{|c|}{100} & \multicolumn{2}{|c|}{150} & \multicolumn{2}{|l|}{200} \\
\hline & & 1 & 3 & 1 & 2 & 1 & 7 \\
\hline \multirow{2}{*}{$\begin{array}{l}\text { Adhesive } \\
\text { /potting }\end{array}$} & EA9394C-2 & \multicolumn{6}{|c|}{$\mathrm{H}_{2} \downarrow ; \mathrm{O}_{2} \downarrow ; \mathrm{CH}_{4} \uparrow ; \mathrm{H}_{2} \mathrm{O} \uparrow ; \mathrm{CO} \uparrow ; \mathrm{CO}_{2} \uparrow$} \\
\hline & AF131-2 & \multicolumn{6}{|c|}{ no significant changes } \\
\hline \multirow{2}{*}{$\begin{array}{l}\text { Thread } \\
\text { Locker }\end{array}$} & Loctite 294 & & & & & \multicolumn{2}{|l|}{$\mathrm{O}_{2} \downarrow ; \mathrm{H}_{2} \mathrm{O} \uparrow ; \mathrm{CO} \uparrow ; \mathrm{CO}_{2} \uparrow ;-\mathrm{CH}_{3} l-\mathrm{CH}_{2}-\uparrow$} \\
\hline & Resbond 507TS & & & & & \multicolumn{2}{|l|}{$\mathrm{O}_{2} \downarrow ; \mathrm{H}_{2} \mathrm{O} \uparrow ; \mathrm{CO} \uparrow ; \mathrm{CO}_{2} \uparrow ;-\mathrm{CH}_{3}-\mathrm{CH}_{2}-\uparrow$} \\
\hline \multirow{2}{*}{$\begin{array}{l}\text { Shrink } \\
\text { Tubing }\end{array}$} & ETFE & & & & & \multicolumn{2}{|l|}{$\mathrm{CO} \uparrow ;-\mathrm{CH}_{3} /-\mathrm{CH}_{2}-\uparrow ; \mathrm{C}-\mathrm{F} \uparrow$} \\
\hline & SRFR & & & & & \multicolumn{2}{|l|}{$\begin{array}{l}\mathrm{O}_{2} \downarrow ; \mathrm{CH}_{4} \uparrow ; \mathrm{H}_{2} \mathrm{O} \uparrow ; \mathrm{CO}_{2} \uparrow ;-\mathrm{CH}_{3} /-\mathrm{CH}_{2}-\uparrow \\
\text { Silicone vapor }\end{array}$} \\
\hline \multirow{2}{*}{ O-ring } & S1151 & & & & & \multicolumn{2}{|l|}{$\mathrm{CO} \uparrow ;-\mathrm{CH}_{3} /-\mathrm{CH}_{2}-\uparrow ;$ Silicone vapor $\uparrow$} \\
\hline & Z1028 & \multicolumn{6}{|c|}{ no significant changes } \\
\hline
\end{tabular}

* Outgassing from trapped volatiles vs. chemical reaction by-products vs. thermal degradation 


\section{Extended Evaluations: TCIOP Material Compatibility}

\section{Residual Property Characterizations Summary}

\begin{tabular}{|c|c|c|c|c|c|}
\hline & Properties* & Physical & Chemical & Thermal & Mechanical \\
\hline \multirow{2}{*}{$\begin{array}{l}\text { Adhesive/ } \\
\text { potting }\end{array}$} & EA9394C-2 & $\Delta \mathrm{Wt} \% \uparrow$ & - & $\mathrm{T}_{\mathrm{g}} \uparrow ; \%$ cure $\uparrow ; \mathrm{G}^{\prime} \uparrow ; \mathrm{T}_{\mathrm{d}} \uparrow$ & Bond strength $\downarrow$ \\
\hline & AF131-2 & $\Delta \mathrm{Wt} \% \downarrow$ & - & $\mathrm{T}_{\mathrm{g}} \uparrow ; \%$ cure $\uparrow ; \mathrm{G}^{\prime} \uparrow ; \mathrm{T}_{\mathrm{d}} \downarrow$ & Bond strength $\uparrow$ \\
\hline \multirow{2}{*}{$\begin{array}{l}\text { Thread } \\
\text { Locker }\end{array}$} & Loctite 294 & $\Delta \mathrm{Wt} \%$, joint \#8个 & - & $\mathrm{n} / \mathrm{a}$ & Torque strength $\uparrow$ \\
\hline & Resbond 507 & $\Delta \mathrm{Wt} \%$, joint \#8个 & - & $\mathrm{n} / \mathrm{a}$ & Torque strength $\uparrow$ \\
\hline \multirow{2}{*}{$\begin{array}{l}\text { Shrink } \\
\text { Tubing }\end{array}$} & ETFE & $n / a$ & - & $\mathrm{T}_{\mathrm{d}} \uparrow$ & Notch strength $\uparrow$ \\
\hline & SRFR & $\mathrm{n} / \mathrm{a}$ & $\begin{array}{l}\Delta \uparrow, \text { oxidation, } \\
\text { side-chain }\end{array}$ & $T_{m} \downarrow ; T_{d} \downarrow ; T_{t} \uparrow$ & Notch strength $\downarrow$ \\
\hline \multirow{2}{*}{ O-ring } & S1151 & $\mathrm{n} / \mathrm{a}$ & $\begin{array}{l}\Delta \uparrow, \text { oxidation, } \\
\text { side-chain }\end{array}$ & $\mathrm{T}_{\text {exo }} \downarrow ; \mathrm{T}_{\mathrm{d}} \downarrow ; \mathrm{T}_{\mathrm{t}} \uparrow$ & $\mathrm{C}_{B} \downarrow ; \mathrm{E}_{Y} \uparrow ; \sigma_{f} \downarrow ; \varepsilon_{f} \downarrow$ \\
\hline & Z1028 & $\mathrm{n} / \mathrm{a}$ & - & $T_{\text {exo }} \downarrow$ & $\mathrm{C}_{B} \downarrow ; \varepsilon_{f} \downarrow$ \\
\hline
\end{tabular}




\section{Summary and Conclusions}

- Multi-step evaluation process was successfully performed to screen and down-select the best HT candidates for various organic materials for future Stirling convertor application.

- As a part of the evaluation, processing and installation conditions of the candidates have been optimized for their applications.

- The application limits of all material candidates were also identified based off the extensive property and performance data.

- The highest service temperature of the final candidates shall be further validated by the synergistic durability life testing (SDLT) 


\section{Summary and Conclusions, Cont'd}

\begin{tabular}{|c|c|c|c|c|}
\hline $\begin{array}{l}\text { Organic } \\
\text { Type }\end{array}$ & $\begin{array}{l}\text { Down-selected } \\
\text { Candidates }\end{array}$ & $\begin{array}{l}\text { Application } \\
\text { limit }\end{array}$ & Strength & $\begin{array}{l}\text { Final } \\
\text { Selection }\end{array}$ \\
\hline \multirow{2}{*}{$\begin{array}{l}\text { Adhesive } \\
\text { /potting }\end{array}$} & EA9394C-2 & $\sim 225^{\circ} \mathrm{C}$ & Thermal stability & $\sqrt{ }$ \\
\hline & AF131-2 & $180-200^{\circ} \mathrm{C}$ & Material compatibility & \\
\hline \multirow{3}{*}{$\begin{array}{l}\text { Thread } \\
\text { Locker }\end{array}$} & Loctite 294 & $\sim 225^{\circ} \mathrm{C}$ & Thermal stability & \\
\hline & Resbond 507TS & $\sim 200^{\circ} \mathrm{C}$ & Locking performance & $\sqrt{ }$ \\
\hline & Poly-Lok PET & $\sim 225^{\circ} \mathrm{C}$ & Thermal stability & \\
\hline \multirow{2}{*}{$\begin{array}{l}\text { Shrink } \\
\text { Tubing }\end{array}$} & ETFE & $\sim 200^{\circ} \mathrm{C}$ & $\begin{array}{l}\text { Thermal stability, material } \\
\text { compatibility }\end{array}$ & $\sqrt{ }$ \\
\hline & SRFR & $\sim 200^{\circ} \mathrm{C}$ & & \\
\hline \multirow[b]{2}{*}{ O-ring } & $S 1151$ & $<200^{\circ} \mathrm{C}$ & & \\
\hline & Z1028 & $\sim 225^{\circ} \mathrm{C}$ & $\begin{array}{l}\text { Thermal stability, material } \\
\text { compatibility }\end{array}$ & $\sqrt{ }$ \\
\hline
\end{tabular}




\section{Future Work Plan}

- Selection of the best candidates thus far was primarily based on the extended thermal aging experiments performed under an inert gas environment and a short-term TCIOP test under a typical Stirling convertor gas environment.

- As per the overall program plan, the final candidates shall be further evaluated and validated via the synergistic durability life tests (SDLT) after combining all convertor organic materials in a simulated Stirling service environment. The tests will consist of radiation exposures (gamma and neutron) and subsequent thermal aging up to 3 years at three temperatures tbd. Three - four aging intervals, also tbd, are planned for outgas analyses and the extensive residual property characterizations.

- Once they are validated, the final process and installation optimizations, and implementation optimizations will be also followed. 


\section{Thank You for your attention!}

Any Questions?

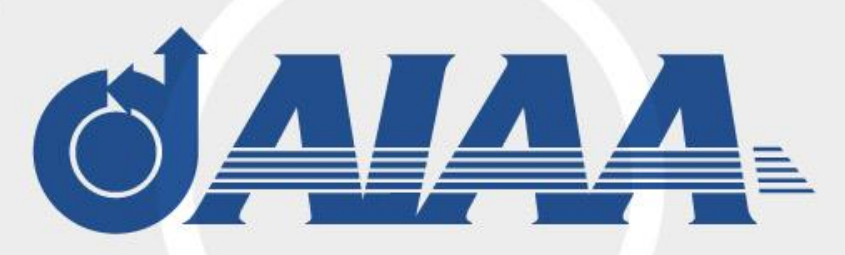

Shaping the Future of Aerospace 